\title{
$\beta$-Estradiol Increases Dentate Gyrus Inhibition in Female Rats via Augmentation of Hilar Neuropeptide $Y$
}

\author{
Jana Velíšková and Libor Velíšek \\ Saul R. Korey Department of Neurology and Dominick P. Purpura Department of Neuroscience, Laboratory of Developmental Epilepsy, Albert Einstein \\ College of Medicine and the Einstein/Montefiore Comprehensive Epilepsy Management Center, Bronx, New York 10461
}

The dentate gyrus filters incoming activity into the hippocampus proper. It plays a role in learning and memory and in pathological states such as epilepsy. Some of hilar interneurons of the dentate gyrus express neuropeptide Y (NPY), which modulates granule cell activity. A subpopulation of the NPY-expressing inhibitory interneurons is sensitive to seizure-induced damage. Pretreatment with $\beta$-estradiol in ovariectomized rats protects hilar interneurons against seizure-induced injury, including the NPY-containing damage-sensitive subpopulation. Here, we demonstrate that $\beta$-estradiol enhances NPY expression within the hilar interneurons. In vitro paired-pulse stimulation of the mixed perforant path revealed $\beta$-estradiol-induced augmentation of granule cell network inhibition, which at interstimulus intervals between 200 and $300 \mathrm{~ms}$ (corresponding to $\sim 3-5 \mathrm{~Hz}$ ) was NPY sensitive and involved $\mathrm{Y}_{1}$ receptors, whereas it was insensitive to $\mathrm{GABA}_{\mathrm{B}}$ or metabotropic glutamate receptor antagonists. Additionally, $\beta$-estradiol pretreatment attenuated propagation of lowfrequency $(3.3$ or $5 \mathrm{~Hz}$ ) burst activity through the dentate gyrus. Scavenging endogenous NPY by intracerebroventricular administration of anti-NPY antibody accelerated kainic acid-induced seizure onset and increased seizure-induced neuronal damage in the hilus compared with rats treated with $\beta$-estradiol alone. Together, we show that $\beta$-estradiol upregulates hilar NPY and that this leads to enhancement in dentate gyrus inhibition of incoming frequencies between 3 and $5 \mathrm{~Hz}$. Such frequencies are similar to the discharge frequencies recorded during seizure initiation in some patients with epilepsy. Thus, $\beta$-estradiol-induced NPY-sensitive filtering of $3-5 \mathrm{~Hz}$ frequencies may be an important regulator of incoming seizure activity, but it could also serve a physiological purpose in modulating information flow into the hippocampus proper.

Key words: epilepsy; dentate gyrus; neuronal excitability; neuroprotection; estradiol; neuropeptide Y

\section{Introduction}

Estrogens regulate gene expression and play an important role in modulation of neuronal activity. The effects of estrogens are mediated mainly by $\beta$-estradiol. The hippocampus represents an important target for $\beta$-estradiol, with most studies performed in the CA1 region (McEwen, 2002). There is little information on estrogen effects in regulation of neuronal excitability in the hippocampal dentate gyrus (Velíšková, 2007). This region is involved in complex biological functions, such as learning and memory consolidation (Pastalkova et al., 2006; Tashiro et al., 2006), and in pathological states, such as epilepsy (Lothman et al., 1992; Behr et al., 1998). It has been proposed that the dentate gyrus may serve as a gate for activity propagation into the hippocampus (Lothman et al., 1992). Dentate granule cell excitability, which is regulated by hilar inhibitory interneurons (Buckmaster and Schwartzkroin, 1995; Ratzliff et al., 2004), seems to determine ability of the dentate gyrus to filter incoming activity.

Received Sept. 29, 2006; revised May 2, 2007; accepted May 5, 2007.

This work was supported by National Institutes of Health Grants NS-41366 and NS-20253 and a Research Grant from CURE Foundation. We thank Drs. S. L. Moshé, P. K. Stanton, and F. A. Lado for constructive comments and scientific discussion during preparation of this manuscript and Dr. C. Hall for consultation in statistics.

Correspondence should be addressed to Dr. Jana Velišková, Albert Einstein College of Medicine, K 312, 1410 Pelham Parkway South, Bronx, NY 10461. E-mail: jvelisko@aecom.yu.edu.

D0I:10.1523/JNEUROSCI.0366-07.2007

Copyright $\odot 2007$ Society for Neuroscience $\quad$ 0270-6474/07/276054-10\$15.00/0
Because hilar interneurons express estrogen receptors (Milner et al., 2001; Kalita et al., 2005), they may be a target of estrogen action.

Under physiological conditions, neuropeptide Y (NPY) is expressed in hilar interneurons. NPY regulates neuronal excitability by activating NPY-specific G-protein coupled receptors (Sperk et al., 1992; Baraban and Tallent, 2004). NPY is involved in modulation of physiological functions, including learning, memory, and anxiety, and in pathological states such as seizures (Vezzani et al., 1999; Heilig, 2004). A subpopulation of NPY-expressing hilar interneurons is especially vulnerable to seizure-induced injury (de Lanerolle et al., 1989). Loss of inhibitory interneurons contributes to increased dentate granule cell excitability (Martin and Sloviter, 2001) and may disrupt the ability of the dentate gyrus to filter incoming seizure activity (Heinemann et al., 1992). When the activity can propagate into hippocampus, it may lead to neuronal injury and intractable seizures (Engel et al., 1997; Mathern et al., 1997).

Chronic pretreatment with low doses $(2 \mu \mathrm{g} / \mathrm{d}$ per rat) of $\beta$-estradiol prevents the loss of hilar neurons, including the NPYexpressing interneurons and the associated increase in granule cell excitability after prolonged seizures (status epilepticus) (Velíšek and Velíšková, 2002; Velíšková, 2006). The same dose of $\beta$-estradiol also delays the onset of kainic acid-induced seizures (Velíšková et al., 2000). Regulation of NPY expression by 
$\beta$-estradiol has been observed in other brain regions (Titolo et al., 2006), including the hippocampal CA1 field (Nakamura and McEwen, 2005), but such interaction has not been studied in the dentate gyrus. NPY upregulation protects against damage of hilar neurons (El Bahh et al., 2001) and delays seizure onset (Richichi et al., 2004; El Bahh et al., 2005). Given these positive and parallel effects of $\beta$-estradiol or NPY pretreatment on seizure-induced damage and on seizure susceptibility, we investigated $\beta$-estradiol-NPY interactions in the dentate gyrus. We determined $\beta$-estradiol-induced changes in NPY expression using immunohistochemistry and stereological counting. We studied synergistic influences of $\beta$-estradiol-NPY interactions in regulation of dentate gyrus network excitability using in vitro recordings. Finally, we used an in vivo approach to confirm that $\beta$-estradiol-NPY interactions are implicated in seizure susceptibility and protection of hilar neurons against seizureinduced damage.

\section{Materials and Methods}

Animals. Experiments were performed according to the Revised Guide for the Care and Use of Laboratory Animals and approved by the Albert Einstein College of Medicine Animal Care and Use Committee. Adult female Sprague Dawley rats (150-175 g; Taconic Farms, Germantown, NY) were used and kept on a $12 \mathrm{~h}$ light/dark cycle (lights on at 7:00 A.M.) with food and water ad libitum. All rats were ovariectomized (OVX) under ether anesthesia. After $7 \mathrm{~d}$, rats were injected subcutaneously with either $17 \beta$-estradiol benzoate ( $\beta$-estradiol; $2 \mu \mathrm{g} / 0.1 \mathrm{ml}$; Sigma, St. Louis, $\mathrm{MO})$ or oil ( $0.1 \mathrm{ml}$; controls) for 4 consecutive days. Additional rats received either a single $\beta$-estradiol or oil injection.

Immunohistochemistry. Rats were perfused transcardially with $4 \%$ formaldehyde [four doses $(4 \times)$ oil, $n=5 ; 4 \times \beta$-estradiol, $n=4$ ]. Brains were removed from the skull and postfixed in the same fixative overnight, cryoprotected with a $30 \%$ sucrose solution in PBS, pH 7.4, and frozen on dry ice. Staining was performed on free-floating coronal sections (40 $\mu \mathrm{m})$ using our standard protocol for immunohistochemistry with the avidin-biotin peroxidase method (Ravizza et al., 2002). We used rabbit anti-NPY polyclonal antibody (1:2000; Sigma). NPY-immunoreactive neurons were visualized with $3^{\prime}-3^{\prime}$-diaminobenzidine using the avidinbiotin horseradish peroxidase method (Vectastain ABC kit; Vector Laboratories, Burlingame, CA). Sections were then mounted on gelatinized slides, dehydrated, and coverslipped with Permount (Fisher Scientific, Pittsburgh, PA). To minimize differences between the various sets of immunohistochemistry, all sections were treated exactly the same way at all steps.

Control sections were prepared using the primary antiserum preabsorbed with the peptide or by incubating the sections without the primary antibodies: under both conditions, the immunohistochemical procedure failed to show any immunoreactivity.

Cell counts. Two independent observers, one of them blind to experimental conditions, performed cell counts. All sections throughout the hippocampus were collected, counted, and filed. The stereological counting was performed according to the West method (West, 2002). Our areas of interests were the hilus (defined as the area surrounded by the layer of dentate granule cells and an imaginary connection between the ends of both granule cell blades except for interposed layer of pyramidal neurons of CA3) and CA1 hippocampal region. Only the dorsal hippocampus has been examined [between the level of bregma -2.12 and $-4.52 \mathrm{~mm}$ (Paxinos and Watson, 1998)], and, for the in vitro recordings, slices have also been cut from the dorsal hippocampus. Every sixth section that contained the area of interest was chosen for examination after selecting randomly the first one within the first interval ( 12 sections for each animal). This was the section sampling fraction (ssf). All NPYpositive neurons with intact morphology, which came to focus within the dissector height, were counted in each area of interest. The optical dissector height $(\mathrm{h})$ relates to a known fraction of section thickness $(\mathrm{t})$. Height of the optical dissector was $10 \mu \mathrm{m}$. Then, the estimated number of neurons is $\Sigma Q \times 1 / \mathrm{ssf} \times \mathrm{t} / \mathrm{h}$, in which $\Sigma Q$ is the total number of neurons counted in the region of interest. The data were compared between the groups.

In vivo anti-NPY antibody treatment. Six days after the ovariectomy ( $4 \times$ oil, $n=13 ; 4 \times \beta$-estradiol, $n=13$ ), unilateral stainless steel cannula was stereotaxically implanted into the third ventricle (anteroposterior, $-3 \mathrm{~mm}$; lateral, $0.1 \mathrm{~mm}$; depth, $-4.5 \mathrm{~mm}$; incisor bar at $-3.5 \mathrm{~mm}$ ) under combined ketamine $(70 \mathrm{mg} / \mathrm{kg})$ and xylazine $(7 \mathrm{mg} / \mathrm{kg})$ anesthesia administered intraperitoneally. Mini-osmotic pumps (ALZET model 1002; ALZA, Mountain View, CA) were placed between the shoulder blades and connected to the cannula via a catheter. ALZET pumps were filled with the anti-NPY antibody (1:5) or normal rabbit serum (NRS) (1:3). This concentration of antibody has been shown to accelerate the kindling rate with no influence on spontaneous behavior or the background EEG activity (Reibel et al., 2003). The dilution of both agents was adjusted to ensure similar protein content of $\sim 10 \mu \mathrm{g} / \mu \mathrm{l}$. The anti-NPY antibody (Sigma) was developed in rabbit using synthetic porcine NPY conjugated to keyhole limpet hemocyanin as immunogen. The pump delivered a continuous flow of solution at a rate of $0.25 \mu \mathrm{l} / \mathrm{h}$. The antiNPY treatment started $1 \mathrm{~d}$ before $\beta$-estradiol treatment and continued until the end of the experiment. The spread of the anti-NPY antibody was determined using immunohistochemistry omitting the primary antibody and detected as NPY-positive staining. The area, in which the antibody did not penetrate, was immunonegative.

Kainic acid-induced seizures. Rats with the ALZET pump implants (see above) were injected with kainic acid $(15 \mathrm{mg} / \mathrm{kg}$, i.p.; Ocean Produce International, Shelburne, Nova Scotia, Canada) (Velišková et al., 2000). The behavior was continuously registered using a video monitoring system for subsequent analysis of seizure severity. Only rats with continuous long-lasting behavioral seizures (status epilepticus lasting at least $4 \mathrm{~h}$ ) were used. The status epilepticus was terminated by pentobarbital (50 $\mathrm{mg} / \mathrm{kg}$, i.p.) after $4 \mathrm{~h}$. The following parameters were analyzed: latency to first forelimb clonus and latency to status epilepticus onset.

FluoroJade B staining. This is a sensitive method for detecting dying neurons (Pitkanen et al., 2002). All rats were transcardially perfused $2 \mathrm{~d}$ after the status epilepticus. Coronal sections $(30 \mu \mathrm{m})$ containing the dorsal hippocampus [between the level of bregma -2.12 and $-4.52 \mathrm{~mm}$ (Paxinos and Watson, 1998)] were cut on a cryostat at $-20^{\circ} \mathrm{C}$. Every fifth section was collected (16 sections in each animal). Mounted sections were immersed in alcohol with $1 \% \mathrm{NaOH}$, transferred into $0.06 \%$ potassium permanganate, and then incubated with FluoroJade B $(0.0004 \%$; Histo-Chem, Jefferson, AR), followed by washing in $0.1 \mathrm{M}$ PBS, dried, soaked in xylene, and coverslipped with Permount.

Brain slice preparation and paired-pulse paradigm. Rats were decapitated under deep ether anesthesia $24 \mathrm{~h}$ after the last $\beta$-estradiol/oil injection. Horizontal slices ( $4 \times$ oil, $n=22 ; 4 \times \beta$-estradiol, $n=22 ; 1 \times$ oil, $n=18 ; 1 \times \beta$-estradiol, $n=8)$ containing the dorsal hippocampus ( 400 $\mu \mathrm{m}$ thick) were cut on a vibratome in ice-cold artificial CSF (ACSF) (in mM: $126 \mathrm{NaCl}, 5 \mathrm{KCl}, 1.25 \mathrm{NaH}_{2} \mathrm{PO}_{4}, 2 \mathrm{MgCl}_{2}, 2 \mathrm{CaCl}_{2}, 26 \mathrm{NaHCO}_{3}$, and 10 glucose, $\mathrm{pH}$ 7.36). The slices were preincubated in an interface chamber in warmed $\left(34-35^{\circ} \mathrm{C}\right)$ and oxygenated $\operatorname{ACSF}\left(5 \% \mathrm{CO}_{2} / 95 \% \mathrm{O}_{2}\right)$ for at least $1 \mathrm{~h}$. Paired square pulses (50-400 $\mu \mathrm{A}, 150 \mu$ s duration) were delivered via a stainless steel bipolar stimulating electrode (Frederick Haer Company, Bowdoinham, ME) positioned over the outer and middle third of the molecular layer (mixed perforant path stimulation) (Velíšek and Velíšková, 2002) using a stimulator coupled to a stimulus isolation unit (A.M.P.I., Jerusalem, Israel). Interstimulus intervals between the paired stimuli ranged from 10 to $1000 \mathrm{~ms}$, corresponding to frequencies of 100 to $1 \mathrm{~Hz}$. The paired stimuli were repeatedly applied to the same tissue every $30 \mathrm{~s}$. This interval ensured full recovery between stimuli so that the response to one stimulus pair was not affected by the previous stimulus pair (Haas et al., 1996). Extracellular evoked responses (population spikes) were recorded using glass recording micropipette (1-5 $\mathrm{M} \Omega$ ) filled with $2 \mathrm{M} \mathrm{NaCl}$ placed in the middle third of the external blade of the dentate gyrus granule cell layer (stratum granulosum). We preferred to record extracellular network (population) responses because $\beta$-estradiol may have differential effects in individual cells. Transmission of perforant path stimulation through granule cells, i.e., dentate gating, was quantified by measuring population spike amplitude. Data were digitized and computer analyzed using Axoscope software (Molecular 
Devices, Sunnyvale, CA). For each interstimulus interval, 6-10 paired responses were averaged. After an initial cycle of control measurements consisting of 6-10 paired-pulse stimulations at each interstimulus interval between 10 and $1000 \mathrm{~ms}$, test substances were bath introduced to the chamber, followed by a cycle of paired-pulse measurements at each interstimulus interval.

In vitro treatments. To block NPY availability, anti-NPY antibody (1: 1000; Sigma) was bath applied for at least $1 \mathrm{~h}$ before recordings in slices $(4 \times, n=12 ; 4 \times \beta$-estradiol, $n=11)$. After each use of the anti-NPY antibody, the tubing and the recording chamber were flushed for at least 10 min with the ACSF containing bovine serum albumin at 1:1000 to remove remnant anti-NPY antibody, followed by ACSF and then by distilled water for at least $1 \mathrm{~h}$. Control experiments included recordings in slices from $\beta$-estradiol-treated OVX rats $(n=9)$ perfused with the ACSF containing preimmune rabbit serum $[1: 1000$ for $1 \mathrm{~h}$ (Sigma); rabbit was the host for the production of anti-NPY antibody], as well as recordings in slices from OVX oil controls with bath application of antiNPY antibody $(n=12)$ or NPY $[n=7$ (Sigma); $1 \mu \mathrm{M}$ for $1 \mathrm{~h}$ (Klapstein and Colmers, 1997)]. Similar cleaning procedures for the tubing and the chamber were used as described above. To determine the role of $Y_{1}, Y_{2}$, and $\mathrm{Y}_{5}$ NPY receptors, the following specific antagonists to individual NPY receptors were bath applied for at least 30 min before recording: 100 nм 6-[[2-(1-methylethyl)phenyl]] sulfonyl-5-nitro-8-quinolinamine (PD 160170) (Wielgosz-Collin et al., 2002) ( $\mathrm{Y}_{1}$ receptor antagonist; $\left.n=7\right), 30$ or $100 \mathrm{~nm}(S)-N 2$-[[1-[2-[4-[(R,S)-5,11-dihydro-6(6h)-oxodibenz[b,e] azepin-11-yl]-1-piperazinyl]-2-oxoethyl cyclopentyl] acetyl]-N-[2-[1,2dihydro-3,5[4H)-dioxo-1,2-diphyenl-3H-1,2,4-triazol-4-yl] ethyl] argininamide (BIIE 0246) (El Bahh et al., 2002; Tu et al., 2005) (Y receptor antagonist; $30 \mathrm{~nm}, n=8$; $100 \mathrm{~nm}, n=6)$, and 250 nм 5,5-dimethyl-2-(2,3,4,9tetrahydro-3,3-dimethyl-1 oxo-1H-xanthen-9-yl)-1,3-cyclohexanedione $(\mathrm{L}-152,804)$ (Woldbye et al., 2005) $\left(\mathrm{Y}_{5}\right.$ receptor antagonist; $\left.n=5\right)$. To determine the role of $\mathrm{GABA}_{\mathrm{B}}$ receptors in the $\beta$-estradiol-induced enhancement of the late paired-pulse inhibition, $400 \mu \mathrm{M}$ (3-aminopropyl)(diethoxymethyl)phosphinic acid (CGP 35348) (Velíšek and Velíšková, 2002) was bath applied for at least $30 \mathrm{~min}$ before recordings $(n=10)$. LY 341495 [(2S)-2-amino-2-[(1S,2S)-2-carboxycycloprop-1-yl]-3(xanth-9-yl) propanoic acid] was bath applied for at least $30 \mathrm{~min}$ before recordings at $20 \mu \mathrm{M}(n=8)$ or $200 \mathrm{nM}(n=7)$ to determine the role of metabotropic glutamate receptors (mGluRs) in the effects of $\beta$-estradiol pretreatment. In micromolar concentrations, LY 341495 is a broad-spectrum mGluR antagonist (Fitzjohn et al., 1998). At nanomolar concentrations, it is a selective group II mGluR antagonist (Fitzjohn et al., 1998). All antagonists to NPY, $\mathrm{GABA}_{\mathrm{B}}$, and metabotropic glutamate receptors were purchased from Tocris Bioscience (Ellisville, MO).

An individual slice was used for recording of a control paired-pulse cycle plus one additional cycle testing one of the listed treatments. We used a maximum of two slices from one rat for any of the conditions.

Burst activity propagation. This experiment was designed to confirm that the $\beta$-estradiol treatment decreases propagation of burst activity through the dentate gyrus at frequencies identified in the paired-pulse paradigm as NPY sensitive $(3.3-5 \mathrm{~Hz})$. Brain slices containing the dorsal hippocampus from $4 \times \beta$-estradiol-treated $(n=7)$ or $4 \times$ oil-injected rats $(n=7)$ were prepared as above. Mixed perforant path was stimulated with a burst of six rectangular monophasic pulses with the intensity at $70 \%$ of the current eliciting maximal response in the granule cell layer. We tested responses of granule cell network to bursts of low-frequency stimulation at frequencies of 3.3 and $5 \mathrm{~Hz}$ corresponding to the NPYsensitive paired-pulse intervals ( 300 and $200 \mathrm{~ms}$, respectively) and to an arbitrarily chosen control high-frequency stimulation at a frequency of $20 \mathrm{~Hz}$, which corresponded to an NPY-insensitive paired-pulse interstimulus interval $(50 \mathrm{~ms})$. We evaluated the ratio of the sixth response to the first to determine the transmission of burst activity through the dentate gyrus. Results were compared between $\beta$-estradiol-treated and oilinjected rats.

Statistics. In every statistical evaluation presented here, tests for normality and variance were run on the data. Because we consistently found Gaussian distribution and similar variances among the groups compared in the individual tests, parametric statistics was used.
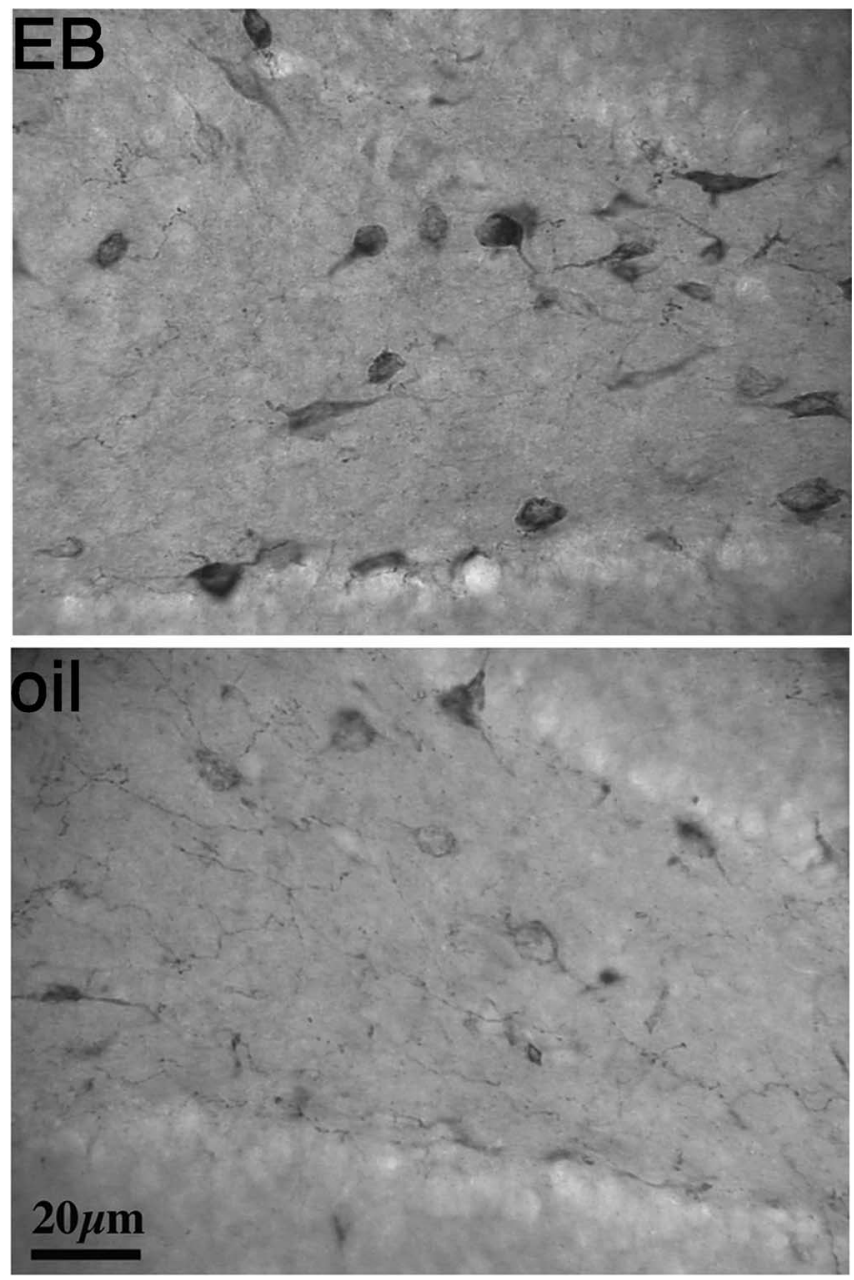

Figure 1. Repeated $\beta$-estradiol administration increases the number of NPY-expressing neurons in the hilus of dentate gyrus. Administration of $\beta$-estradiol ( $4 \times$ estradiol) in OVX rats resulted in increased number of NPY-immunopositive cells in the hilus of the dorsal hippocampus at $24 \mathrm{~h}$ after the last injection compared with control OVX oil controls. Stereological cell counts revealed a significant increase in the number of NPY-immunopositive cells in the hilus of $\beta$-estradiol-pretreated OVX rats compared with OVX oil controls (Student's $t$ test, ${ }^{*} p<0.05$ ).

Latency to onset of kainic acid-induced clonic seizures was compared using one-way ANOVA (factor of treatment) followed by pairwise post hoc Fisher's protected least significance difference test. Cell counts were compared between the two conditions (oil vs $\beta$-estradiol pretreatment) using two-tailed Student's $t$ test. The ratio of the second (test) population spike amplitude to the amplitude of the first (conditioning) population spike in the response averaged from 6-10 stimulations also yielded normally distributed values with similar variances across different groups. For the initial evaluation comparing test and control conditions, we used ANOVA. If differences were significant, we used Duncan's multiple range $t$ test to compare interstimulus interval-matched data (Derbenev et al., 2006). Every individual data subset entered post hoc analysis only once. Level of significance was always preset to $p<0.05$.

\section{Results \\ $\beta$-Estradiol increases NPY expression within the hilar interneurons}

Consistent with a preliminary report in an abstract form (Velís ková, 2003), NPY immunoreactivity was detected in significantly higher number of neurons in the hilar region of $\beta$-estradioltreated rats $(n=4)$ compared with OVX controls $(n=5)$ that received oil (vehicle) injections ( $\beta$-estradiol, $41.16 \pm 5.5 \times 10^{3}$; 

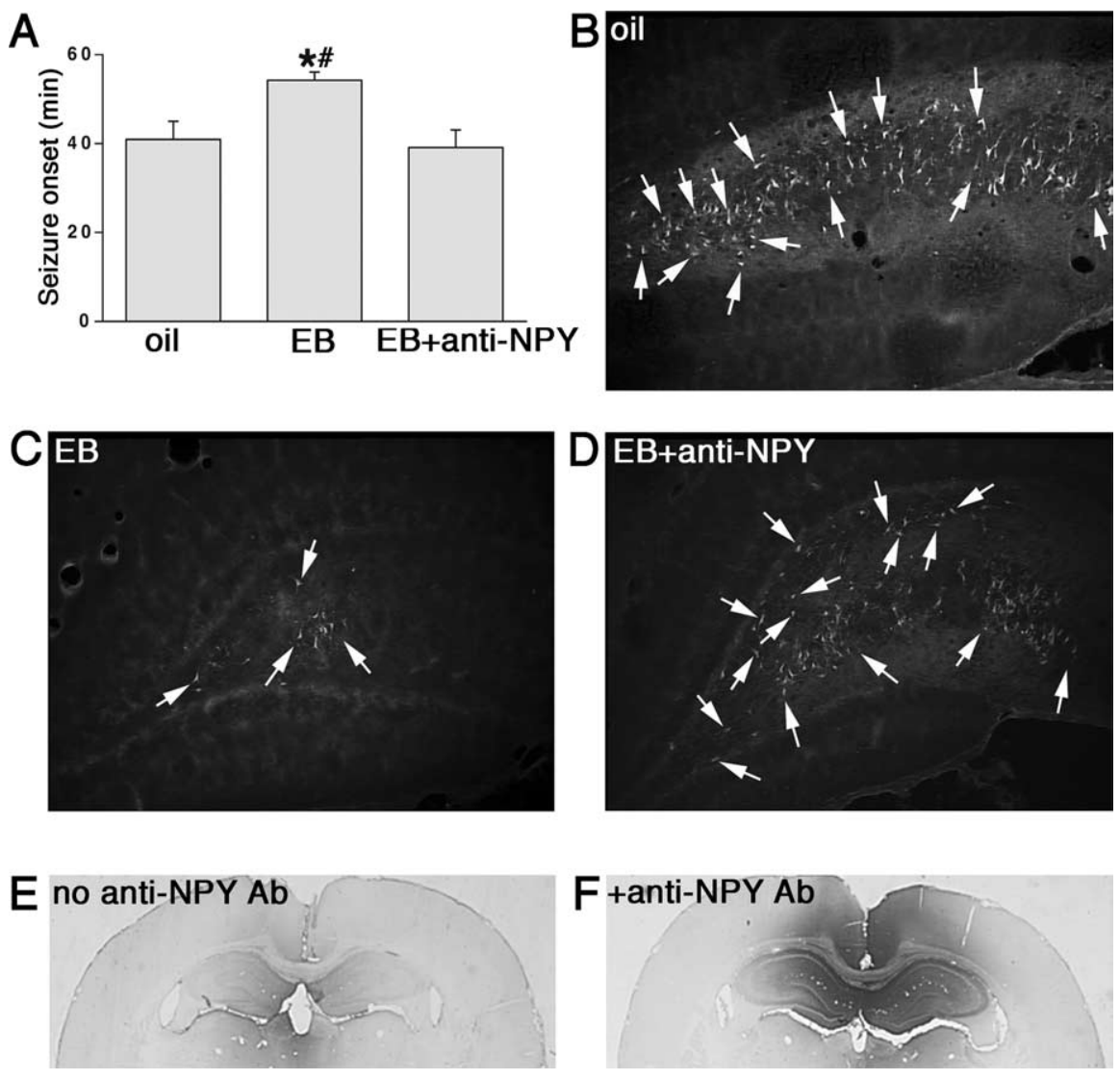

Figure 2. In vivo scavenging of $\beta$-estradiol-induced NPY upregulation is sufficient to abolish $\beta$-estradiol anticonvulsant and neuroprotective effects. OVX female rats with implanted ALZET pumps delivering anti-NPY antibody via an intracerebroventricular cannula were treated with four daily doses of $\beta$-estradiol (EB). Rats were challenged with kainic acid $24 \mathrm{~h}$ after the last $\beta$-estradiol injection. $\boldsymbol{A}$, The $\beta$-estradiol (EB)-mediated increase in seizure threshold was abolished by a blockade of NPY effects in the dentate gyrus. Latency to onset of first kainic acid-induced clonic seizure is shown (mean \pm SEM; estradiol vs oil, ${ }^{\#} p<0.0001$; estradiol vs estradiol plus anti-NPY, ${ }^{*} p<0.0001$; estradiol plus anti-NPY vs oil, $\left.p>0.05\right)$. $\boldsymbol{B}-\boldsymbol{D}$, In oil-injected rats $(\boldsymbol{B})$, hilar region contained numerous FluoroJade B-positive neurons after kainic acid-induced status epilepticus. The neuroprotective effect of $\beta$-estradiol $(\boldsymbol{C})$ against status epilepticus-induced hilar damage was abolished by intracerebroventricular infusion of anti-NPY antibody ( $\boldsymbol{D})$. Arrows point to some of many FluoroJade B-positive neurons, indicating cell injury. $\boldsymbol{E}, \boldsymbol{F}$, Antibody (Ab) penetration into the tissue was confirmed by immunohistochemistry omitting the incubation with primary antibody. An immunonegative result marks lack of anti-NPY antibody in the tissue $(\boldsymbol{E})$, whereas immunopositive staining reveals successful penetration of the anti-NPY antibody in the hippocampal tissue $(\boldsymbol{F})$.

oil, $22.51 \pm 3.17 \times 10^{3}$; Student's $t$ test, $\left.{ }^{\star} p<0.05\right)$. The NPYpositive neurons in $\beta$-estradiol-treated rats appeared darker than the ones in oil-injected rats (Fig. 1). It should be noted here that the immunohistochemistry was always performed in parallel on slices from $\beta$-estradiol-treated and oil-injected animals, and the individual steps of the procedure were strictly the same to allow comparisons between the treatments. Treated rats received four daily injections of $2 \mu \mathrm{g} / \mathrm{rat} \beta$-estradiol, which produces plasma levels of $\beta$-estradiol within the physiological range (Neal-Perry et al., 2005). Because a recent study focusing specifically on the CA1 region showed enhanced NPY mRNA expression as well as increased number of NPY-immunoreactive neurons after $10 \mu \mathrm{g} / \mathrm{rat}$ $\beta$-estradiol (Nakamura and McEwen, 2005), we also determined changes in the NPY expression in CA1. The $2 \mu \mathrm{g} /$ rat dose of $\beta$-estradiol used in the present study did not increase the number of NPY-expressing neurons in the CA1 region compared with oil controls (Student's $t$ test, $p=0.80$ ). In addition, there were no such apparent differences in the immunointensity between $\beta$-estradiol-treated and oil-injected animals in the CA1 region as we observed in the hilus.

\section{$\boldsymbol{\beta}$-Estradiol-mediated increase in hilar NPY plays a role in kainic acid-induced seizures}

Because enhanced expression of NPY in the hilar region is associated with powerful anticonvulsant and neuroprotective actions (Richichi et al., 2004; Dube et al., 2005; Silva et al., 2005), we tested whether $\beta$-estradiol-induced delay in seizure onset and neuroprotective effects were mediated by an increase in NPY. We reduced NPY activity by intracerebroventricular administration of anti-NPY antibody to scavenge the endogenous NPY. The presence of anti-NPY antibody in the hippocampal hilar region in $\beta$-estradioltreated OVX rats $(n=7)$ blocked the $\beta$-estradiol-induced $(n=6)$ increases in seizure latency. Seizure latency in antiNPY $\beta$-estradiol-treated rats was similar to OVX oil $(n=7)$ controls (ANOVA; $\left.F_{(2,17)}=13.15 ;{ }^{\star} p<0.001\right)$ (Fig. $\left.2 A\right)$, in which ovariectomy was associated with low NPY expression (Fig. 1). To confirm that the effect on seizure latency was not attributable to surgery and subsequent intracerebroventricular injection-related stress, we compared the seizure latency in the $\beta$-estradiol-treated OVX rats with intracerebroventricular administration of preimmune (normal) rabbit serum $(n=$ 4 ) to the $\beta$-estradiol-treated OVX rats without any intracranial implants $(n=6)$. Seizure latency was not affected by surgery or subsequent intracerebroventricular administration of normal rabbit serum compared with rats without surgery (Student's $t$ test, $p=0.76)$. As we reported previously (Velíšková et al., 2000), $\beta$-estradiol pretreatment did not prevent development of status epilepticus. In addition, consistent with previous studies, behavioral seizure severity was not affected by $\beta$-estradiol pretreatment (Velíšková et al., 2000; Reibel et al., 2000; Hoffman et al., 2003). Finally, anti-NPY antibody pretreatment also abolished the neuroprotective effect of $\beta$-estradiol in the hilar region as determined by FluoroJade B staining (Fig. $2 B-D$ ).

\section{$\boldsymbol{\beta}$-Estradiol enhances the late paired-pulse inhibition in the dentate gyrus}

We used the in vitro paired-pulse paradigm by stimulating the mixed perforant pathway to assess changes in the dentate granule cell network excitability (Velíšek and Velíšková, 2002). The paired-pulse curve was constructed by calculating population spike amplitude ratio $\left(R_{2} / R_{1}\right)$ at increasing interstimulus intervals. The curve consisted of three components (Haas et al., 1996; Velíšek and Velíšková, 2002) referred to here as (1) early inhibition (10-50 ms), (2) intermediate facilitation (70-125 ms), and (3) late inhibition (150-1000 ms). Slices from OVX females treated with four daily doses of $\beta$-estradiol $(2 \mu \mathrm{g} / \mathrm{rat} ; n=22)$ displayed significant enhancement of late paired-pulse inhibition at interstimulus intervals 125-1000 ms compared with slices from OVX controls $(n=22)$ receiving oil (two-way ANOVA; 
main effect of treatment, $F_{(1,42)}=15.871$; $\left.{ }^{*} p<0.001\right)$. The post hoc comparisons revealed significant differences in the following paired-pulse intervals: ${ }^{\star} p_{125-150 \mathrm{~ms}}$ $<0.01 ;{ }^{*} p_{200-1000 \mathrm{~ms}}<0.001$ (Fig. $3 A$ ). There were no changes in paired-pulse paradigm in the interstimulus intervals of $10-100 \mathrm{~ms}\left(p_{10-100 \mathrm{~ms}}>0.05\right)$.

We also tested the effect of a single $\beta$-estradiol ( $2 \mu \mathrm{g})$ dose on granule cell excitability. It is possible that a single dose might increase network excitability, whereas four $\beta$-estradiol injections could elicit a slower, compensatory increase in the network inhibition. Similar phenomenon has been described in the CA1 region after $10 \mu \mathrm{g}$ of $\beta$-estradiol (Rudick and Woolley, 2001). This study showed that inhibitory synaptic input to pyramidal neurons in CA1 decreases after a single $\beta$-estradiol injection, but it increases after two $\beta$-estradiol injections (Rudick and Woolley, 2001).

We found that a single $\beta$-estradiol injection had no effect on paired-pulse profiles (two-way ANOVA; main effect of treatment, $F_{(1,24)}=0.998 ; p>0.05 ; 1 \times$ $\beta$-estradiol, $n=8 ; 1 \times$ oil OVX, $n=18$ ) (Fig. $3 B$ ), suggesting that $\beta$-estradiol does not alter the dentate gyrus network excitability after just one injection.

NPY is involved in $\beta$-estradiol-induced enhancement of paired-pulse inhibition at interstimulus intervals between 200 and $300 \mathrm{~ms}$

We used bath application of anti-NPY antibody to scavenge the endogenous NPY. In slices from OVX rats pretreated with four doses of $\beta$-estradiol $(n=11)$, addition of the anti-NPY antibody $(1: 1000)$ to the ACSF induced a significant loss of paired-pulse inhibition at interstimulus intervals between 200 and $300 \mathrm{~ms}$ (paired $t$ test; ${ }^{\star} p_{200-300 \mathrm{~ms}}<0.05$ ) (Fig. $4 A$ ) but did not significantly influence earlier or later intervals $\left(p_{125-150 \mathrm{~ms}}>0.05 ; p_{500-1000 \mathrm{~ms}}>0.05\right)$. Preimmune normal rabbit serum (1:1000) bath applied to slices from $\beta$-estradioltreated rats $(n=9)$ for at least $1 \mathrm{~h}$ had no effect on the pairedpulse responses affected by the anti-NPY antibody (paired $t$ test, $p_{200-300 \mathrm{~ms}}>0.05$ ) (Fig. $4 B$ ). To confirm the specificity of this effect, NPY was bath applied onto slices from OVX oil-injected rats, which have low NPY levels (Fig. 1). In slices from OVX oil controls $(n=7)$, perfusion with $1 \mu \mathrm{M}$ NPY enhanced the late paired-pulse inhibition selectively and specifically at the interstimulus intervals between 200 and $300 \mathrm{~ms}$ (paired $t$ test, ${ }^{\star} p_{200-}$ $300 \mathrm{~ms}<0.05$ ) (Fig. 4C). Conversely, bath application of anti-NPY antibody in slices from OVX oil controls $(n=12)$ had no effect on the paired-pulse responses (paired $t$ test; $p_{200-300 \mathrm{~ms}}>0.05$ ).

NPY mediates its inhibitory effects in the dentate gyrus of the dorsal hippocampus by inhibition of glutamate release via activating presynaptic $\mathrm{Y}_{1}$ or $\mathrm{Y}_{2}$ receptors (Silva et al., 2001). Because the dorsal hippocampus was the region of our interest, we mainly concentrated on determining the involvement of $Y_{1}$ and $Y_{2} N P Y$ receptor subtypes. Bath application of the NPY $\mathrm{Y}_{1}$ receptor an- tagonist PD 160170 (100 nM; $n=7)$ blocked the $\beta$-estradiolinduced enhancement of the late paired-pulse inhibition at interstimulus intervals of $150 \mathrm{~ms}$ and between 200 and $300 \mathrm{~ms}$ (paired $t$ test, ${ }^{\star} p_{150 \mathrm{~ms}}<0.05$ and ${ }^{\star} p_{200-300 \mathrm{~ms}}<0.01$ ) (Fig. $4 D$ ), suggesting involvement of this NPY receptor subtype. Conversely, bath application of the NPY $\mathrm{Y}_{2}$ receptor antagonist BIIE 0246 (30 nM, $n=8$; or $100 \mathrm{nM}, n=6$ ) had no effect (paired $t$ test, $p_{125-1000 \mathrm{~ms}}>$ 0.05) (Fig. 4E). Finally, activation of NPY $Y_{5}$ receptors may mediate inhibitory effects in the hippocampus as well (Woldbye et al., 2005), although another study did not confirm inhibitory effects of $\mathrm{Y}_{5}$ receptors in the hippocampus (El Bahh et al., 2005). Also, binding studies show that $\mathrm{Y}_{5}$ receptor subtype is preferentially expressed in the ventral hippocampus (Dumont et al., 1998). Accordingly, in our preparation from the dorsal hippocampus, bath application of NPY $\mathrm{Y}_{5}$ receptor antagonist $\mathrm{L}-152,804(250 \mathrm{nM}, n=5)$ did not influence the $\beta$-estradiolinduced effects in the late paired-pulse intervals (paired $t$ test, $\left.p_{125-1000 \mathrm{~ms}}>0.05\right)$ (Fig. $\left.4 F\right)$.

We performed additional experiments to confirm that the effect at the paired-pulse intervals between 200 and $300 \mathrm{~ms}$ is specific for the NPY system. We tested the involvement of the $\mathrm{GABA}_{\mathrm{B}}$ and the mGluR-mediated transmission, which represents the slow inhibition via a second messenger and thus possi- 


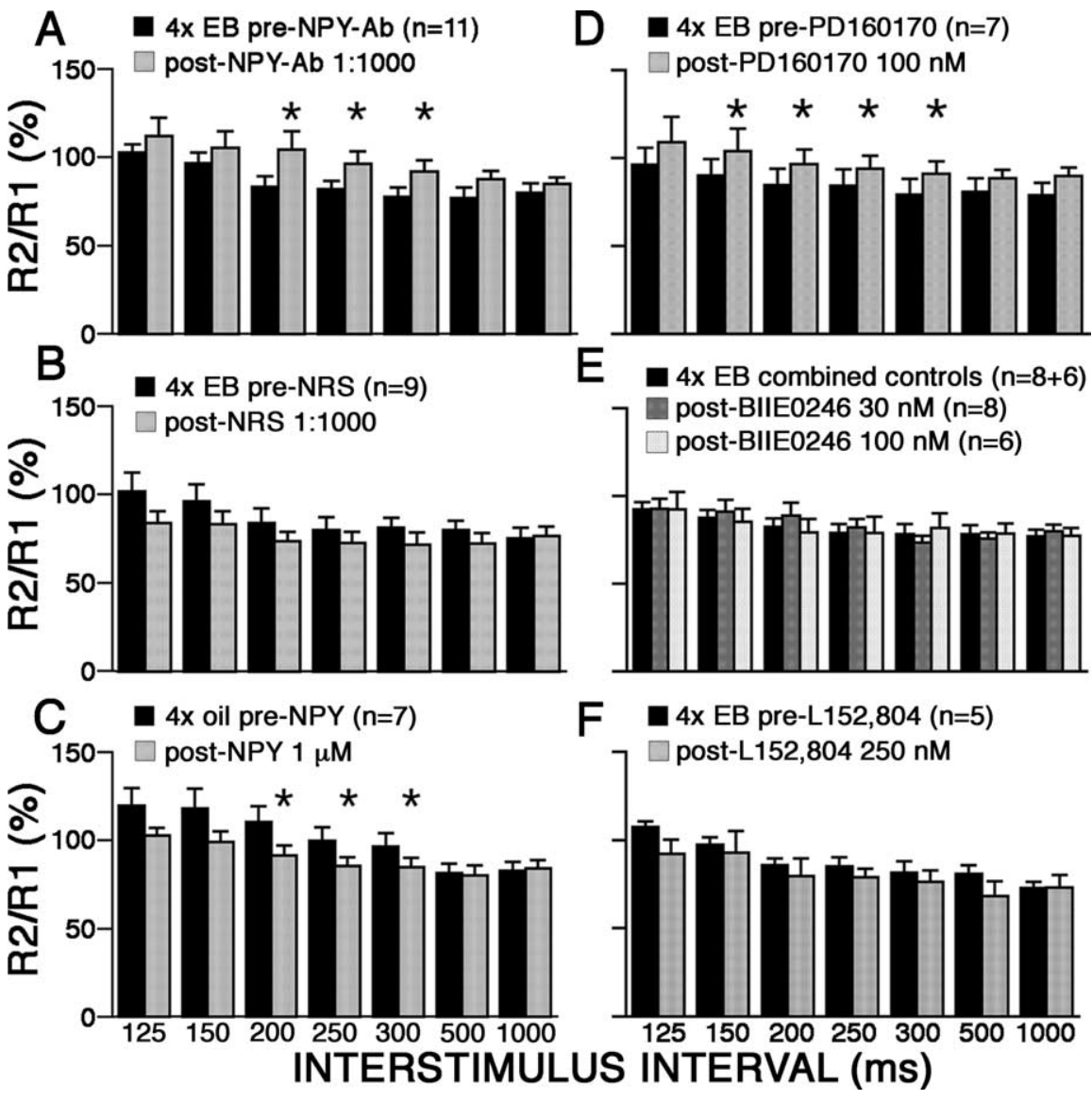

Figure 4. NPY is involved in $\beta$-estradiol-induced increase in late paired-pulse suppression in dentate granule cells after mixed perforant path stimulation. $\boldsymbol{A}$, Bath application of anti-NPY antibody (Ab) (1:1000) to slices from OVX $\beta$-estradiol-treated rats $(4 \times E B)$ significantly suppressed the $\beta$-estradiol-induced enhancement of paired-pulse inhibition at interstimulus intervals between 200 and $300 \mathrm{~ms}$ (paired $t$ test, ${ }^{*} p_{200-300 \mathrm{~ms}}<0.05$ ). The specificity of the NPY-mediated effects has been determined by following experiments $(\boldsymbol{B}-\boldsymbol{F})$. $\boldsymbol{B}$, Bath application of preimmune NRS (1:1000) to slices from OVX $\beta$-estradiol-treated rats $(4 \times E B)$ did not alter the late paired-pulse inhibition (paired $t$ test, $\left.p_{200-300 \mathrm{~ms}}>0.05\right)$. C, Bath application of NPY (1 $\mu \mathrm{M}$ ) to slices from OVX oil controls significantly enhanced the late paired-pulse inhibition at interstimulus intervals between 200 and $300 \mathrm{~ms}$ (paired $t$ test, ${ }^{*} p_{200-300 \mathrm{~ms}}<0.05$ ). D, Bath application of $100 \mathrm{~nm}$ PD160170 (NPY Y ${ }_{1}$ receptor antagonist) to slices from 0VX $\beta$-estradioltreated rats $(4 \times E B)$ significantly suppressed the $\beta$-estradiol-induced enhancement of paired-pulse inhibition at interstimulus intervals of 150 ms and between 200 and 300 ms (paired $t$ test, ${ }^{*} p_{150 \mathrm{~ms}}<0.05$ and ${ }^{*} p_{200-300 \mathrm{~ms}}<0.01$ ), suggesting that $Y_{1}$ receptors are involved in the NPY-mediated inhibitory effects at the perforant path-granule cell network. $\boldsymbol{E}$, Bath application of 30 or $100 \mathrm{~nm}$ BIIE 0246 (NPY Y 2 receptor antagonist) to slices from OVX $\beta$-estradiol-treated rats $(4 \times \mathrm{EB})$ did not alter the late paired-pulse inhibition (paired $t$ test, $p_{125-1000 \mathrm{~ms}}>0.05$ ). $F$, Bath application of L-152,804 (NPY $Y_{5}$ receptor antagonist) to slices from OVX $\beta$-estradiol-treated rats $(4 \times \mathrm{EB})$ did not alter the late paired-pulse inhibition (paired $t$ test, $\left.p_{125-1000 \mathrm{~ms}}>0.05\right)$. All pharmacological manipulations were applied to same slices, in which baseline recordings have been already established. Thus, pretreatment and posttreatment measurements constitute paired data. ${ }^{*} p<0.05$, differences between the two measurements at corresponding interstimulus intervals determined by two-tailed paired $t$ test. $x$-Axis, Interstimulus interval (in milliseconds); $y$-Axis, Ratio of the second response ( $R_{2}$; test) to the first response $\left(R_{1}\right.$; conditioning) as a percentage. Only those interstimulus intervals in which the initial treatments (Fig. 3 ) resulted in significant differences are shown.

bly involved in the late phase of paired-pulse paradigm. Bath application of $400 \mu \mathrm{M}$ of the $\mathrm{GABA}_{\mathrm{B}}$ receptor antagonist CGP $35348(n=10)$ for at least $30 \mathrm{~min}$ before recordings did not have any effect on the late paired-pulse inhibition (two-way ANOVA, $\left.F_{(1,18)}=0.07 ; p_{125-1000 \mathrm{~ms}}>0.05\right)$ (Fig. $5 A$ ).

To test the mGluR system, we used bath application of $20 \mu \mathrm{M}$ LY 341495, which at this concentration is a broad-spectrum mGluR antagonist (Fitzjohn et al., 1998). In slices from $\beta$-estradiol-treated rats $(n=8), 20 \mu \mathrm{M}$ LY 341495 did not influence the NPY-mediated increase in the inhibition at the pairedpulse intervals between 200 and $300 \mathrm{~ms}$ but selectively suppressed the $\beta$-estradiol-induced enhancement of paired-pulse inhibition at the very late $(500-1000 \mathrm{~ms})$ interstimulus intervals (paired $t$

\section{Discussion}

test, $\left.{ }^{\star} p_{500-1000 \mathrm{~ms}}<0.05\right)$ (Fig. $5 B$ ). It is possible that, by blocking all three types of mGluR, the lack of effect may be attributable to antagonizing effects between the excitatory type I mGluRs and the inhibitory type II mGluRs. Thus, we also bath applied LY 341495 using the dose of 200 nM $(n=10)$. At this dose, LY 341495 is a specific group II mGluR antagonist (Fitzjohn et al., 1998). At this concentration, LY 341495 again did not influence the paired-pulse intervals between 200 and $300 \mathrm{~ms}$ but suppressed the $\beta$-estradiolinduced paired-pulse inhibition at $150 \mathrm{~ms}$ interstimulus interval (paired $t$ test, $\left.{ }^{*} p_{150 \mathrm{~ms}}<0.05\right)$ (Fig. 5C).

$\boldsymbol{\beta}$-Estradiol-treatment attenuates the propagation of burst activity through the dentate gyrus

To verify that $4 \times \beta$-estradiol pretreatment may attenuate the propagation of bursting activity through the dentate gyrus at the NPY-sensitive frequencies identified with the paired-pulse paradigm, we used the in vitro stimulation of mixed perforant path with bursts of six pulses delivered either at NPY-sensitive frequencies ( 3.3 or $5 \mathrm{~Hz}$; corresponding to interstimulus interval 300 or $200 \mathrm{~ms}$, respectively) or at the NPY-insensitive frequency $(20 \mathrm{~Hz}$; corresponding to interstimulus interval 50 $\mathrm{ms})$. Propagation of the low-frequency (3.3 or $5 \mathrm{~Hz}$ ) burst activity (expressed as $\mathrm{R}_{6} / \mathrm{R}_{1}$ ) through the dentate gyrus was decreased in slices from $\beta$-estradiol-treated rats compared with slices from oil-injected OVX controls (paired $t$ test, ${ }^{\star} p<0.05$ ) (Fig. 6B). Propagation of the high-frequency stimulation $(20 \mathrm{~Hz})$ was not different between slices from $\beta$-estradiol-treated and oil-injected rats (paired $t$ test, $p>0.05$ ) (Fig. 6B). These data together with the results of the pairedpulse paradigm indicate that the dentate gyrus in $\beta$-estradiol-treated rats can better filter the incoming low-frequency activities at 3-5 Hz (NPY-sensitive) than the dentate gyrus in oil-injected rats. The filtering of high-frequency activities is not affected by $\beta$-estradiol.

Our study has identified several novel mechanisms of $\beta$-estradiol-mediated effects on neuronal excitability in the dentate gyrus. First, the 4 -d $\beta$-estradiol treatment in OVX female rats using a dose that produces estradiol plasma levels within a physiological range increases the number of NPY-immunopositive cells in the dentate hilar region compared with oil controls. Second, this NPY increase is associated with specific enhancement in late phase of paired-pulse inhibition (at interstimulus intervals between 200 and $300 \mathrm{~ms}$ ) in the perforant path-dentate gyrus system determined in vitro and involves activation of NPY $\mathrm{Y}_{1}$ receptors. This effect further extends into increased filtering of 

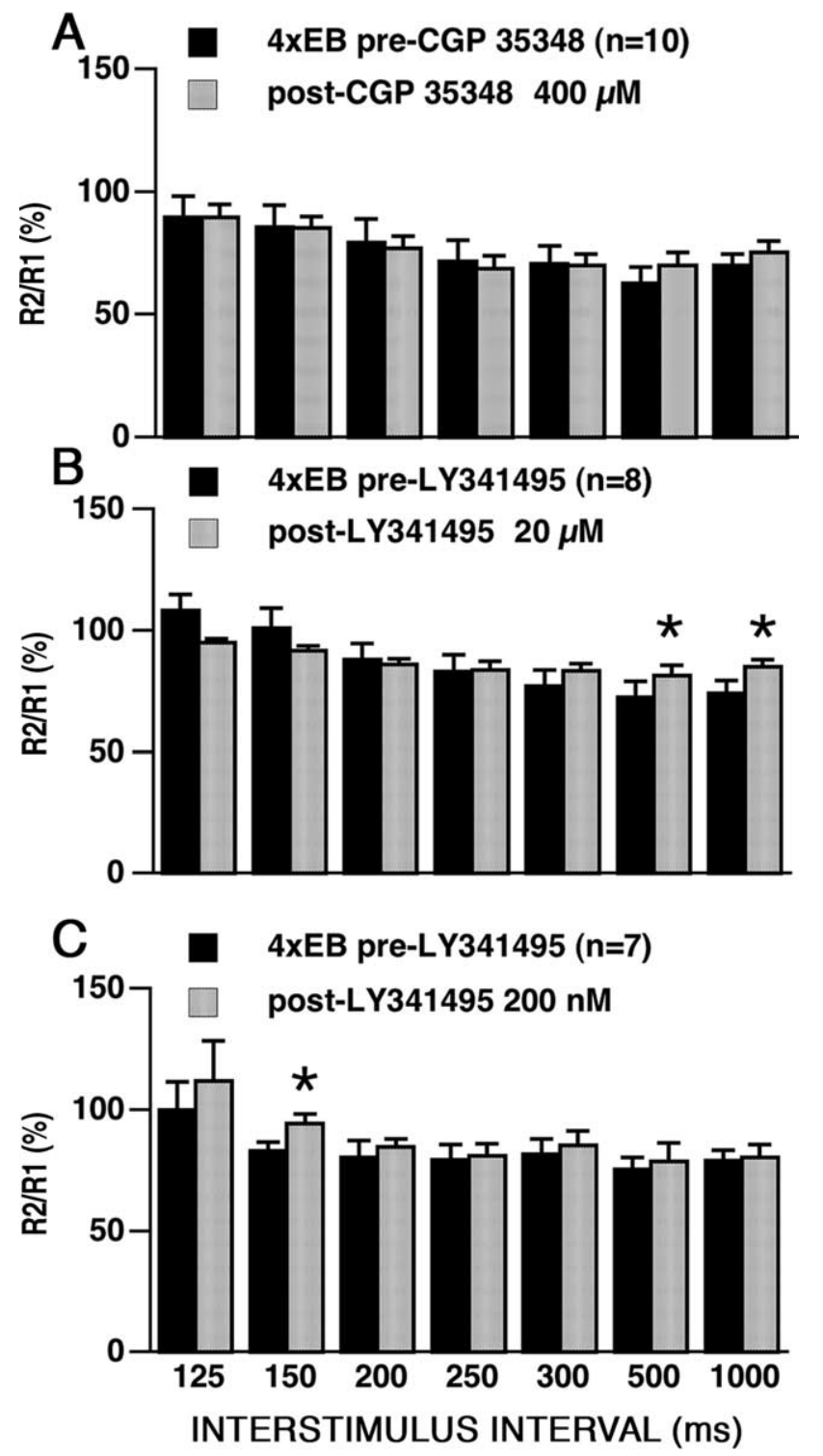

Figure 5. $\mathrm{GABA}_{B}$ or mGluR-mediated transmission is not involved in the $\beta$-estradiolinduced increase in paired-pulse suppression at the NPY-sensitive intervals (200-300 ms). $\boldsymbol{A}$, Bath application of a GABA ${ }_{B}$ receptor antagonist (GP $35348(400 \mu \mathrm{m})$ to slices from OVX $\beta$-estradiol-treated rats (4XEB) did not affect the late paired-pulse inhibition (two-way ANOVA for paired-pulse intervals of $125-1000 \mathrm{~ms} ; p>0.05$ ). $\boldsymbol{B}$, Bath application of $L Y 341495$ $(20 \mu \mathrm{M})$, which at this concentration is a general antagonist for mGluR receptor groups I-III, to slices from $0 \mathrm{VX} \beta$-estradiol treated rats ( $4 \times \mathrm{EB})$ significantly suppressed the $\beta$-estradiolinduced enhancement of paired-pulse inhibition only at interstimulus intervals of 500-1000 ms (paired $t$ test, $\left.{ }^{*} p_{500-1000}<0.05\right)$. C, Additionally, bath application of LY 341495 (200 nM), which at this concentration is a selective group II mGluR antagonist, to slices from OVX $\beta$-estradiol-treated rats ( $4 \times \mathrm{EB})$ significantly suppressed the $\beta$-estradiol-induced enhancement of paired-pulse inhibition at interstimulus interval $150 \mathrm{~ms}$ (paired $t$ test, ${ }^{*} p_{150}<0.05$ ). ${ }^{*} p<0.05$, differences between the two measurements at corresponding interstimulus intervals determined by two-tailed paired $t$ test. $x$-Axis, Interstimulus interval (in milliseconds). $y$-Axis, Ratio of the second response $\left(R_{2}\right.$; test) to the first response ( $R_{1}$; conditioning) as a percentage. Only those interstimulus intervals in which the initial treatments (Fig. 3) resulted in significant differences are shown.

burst discharges between $\sim 3$ and $5 \mathrm{~Hz}$ incoming to the dentate gyrus via the mixed perforant path. Third, $\beta$-estradiol-induced increase in NPY seems to be responsible for delayed onset of kainic acid-induced seizures and neuroprotection against status epilepticus-induced hilar damage because both effects can be blocked by intracerebroventricular administration of anti-NPY

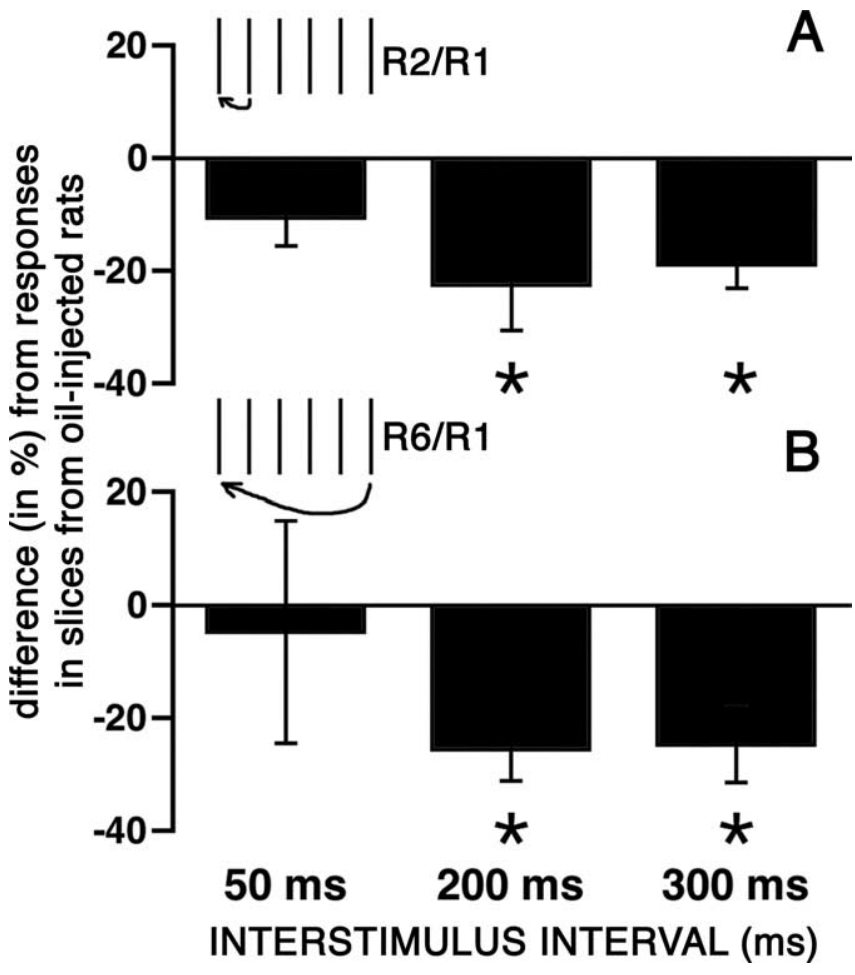

Figure 6. $\beta$-Estradiol pretreatment attenuates propagation of low-frequency but not highfrequency bursts through the dentate gyrus. This experiment confirmed and expanded results of the experiment illustrated in the Figure $3 A$. Differences of the responses recorded in slices from $\beta$-estradiol-treated rats are shown as the percentage of responses recorded in slices from oil-injected rats. $\boldsymbol{A}$, Evaluation of the response to the second stimulus (illustrated by an inset) in the six-pulse train revealed the same pattern as the responses in the paired pulse experiment (Fig. 3A). There was no difference between oil-injected and $\beta$-estradiol-treated rats at $50 \mathrm{~ms}$ interstimulus interval ( $p>0.05$ ), whereas there was a significantly enhanced inhibition in slices from $\beta$-estradiol-treated rats at 200 and 300 ms interstimulus intervals compared with oil-injected controls ( $t$ test, ${ }^{*} p<0.05$ ). $\boldsymbol{B}$, After delivery of burst stimulation consisting of six consecutive pulses with interstimulus intervals of 50,200 , or $300 \mathrm{~ms}$, the response to the last, sixth stimulus (illustrated by an inset) in slices from $\beta$-estradiol-treated (EB) rats was decreased at interstimulus intervals of 200 and $300 \mathrm{~ms}$ (i.e., at frequencies 3.3 or $5 \mathrm{~Hz} ; t$ test, ${ }^{*} p<0.05$ ) but not at the 50 ms interstimulus interval $(20 \mathrm{~Hz} ; p>0.05)$.

antibody. Results from the present study establish a link between the effects of $\beta$-estradiol and NPY and a mechanism to modulate dentate gyrus function.

Repeated administration of a physiological dose of $\beta$-estradiol in OVX females leads to upregulation of NPY in the hilus compared with oil-injected controls, which have a low NPY expression. We speculate that the increased number of immunopositive neurons in the hilus after $\beta$-estradiol treatment may be attributable to enhanced expression of the peptide within the NPYexpressing neurons but not attributable to de novo production of NPY. Overexpression of NPY in the hilus delays seizure onset and has neuroprotective effects (El Bahh et al., 1997; Vezzani and Sperk, 2004). NPY overexpression can be also associated with reduced seizure duration/severity and thus may lead to a decrease of neuronal damage (Richichi et al., 2004; Dube et al., 2005). However, we did not observe a decrease in seizure severity in our study. This finding suggests a possible dissociation between neuroprotective effects of NPY and reduction of seizure severity.

The hilar region-specific effect on NPY expression may be associated with the treatment paradigm of $2 \mu \mathrm{g} / \mathrm{rat} \beta$-estradiol used in this study, whereas a higher dose $(10 \mu \mathrm{g} / \mathrm{rat})$ has been shown to increase NPY expression in the CA1 region (Nakamura and McEwen, 2005). Such biphasic effect is not surprising be- 
cause administration of a $10 \mu \mathrm{g}$ dose of $\beta$-estradiol enhances sensitivity to NMDA receptor-mediated transmission in field CA1 (Woolley et al., 1997), an effect not present after administration of the $2 \mu \mathrm{g}$ dose of $\beta$-estradiol (Velíšek et al., 1999).

The $\beta$-estradiol-induced increase in NPY expression in hilar interneurons leads to trans-synaptic regulation of granule cell activity. Hilar NPY interneurons have axons ramifying in the perforant path terminal field and thus participate in regulation of this major excitatory input to the hippocampus proper (Freund and Buzsaki, 1996). Because we directly stimulated the mixed perforant pathway (in the molecular layer of the dentate gyrus), we do not expect any influence of potential $\beta$-estradiol-induced changes occurring upstream the stimulation site (such as in the entorhinal cortex) because our stimulating/recording paradigm bypasses these influences. The $\beta$-estradiol-induced increase in NPY expression in the hilar region was associated with enhanced dentate gyrus filtering at interstimulus intervals corresponding approximately to the frequencies between 3 and $5 \mathrm{~Hz}$. Indeed, if bursts of stimuli were delivered at these frequencies, the responses of granule cells in $\beta$-estradiol-treated rats were attenuated compared with responses in oil-injected rats. Increased synaptic inhibition at these specific frequencies may be important for filtering of kainic acid-induced epileptiform activity originating in the entorhinal cortex (Ben-Ari et al., 1981), which involves increases in cortical neuronal activity at frequencies of $2-5 \mathrm{~Hz}$ (Medvedev et al., 2000). Also in patients with temporal lobe epilepsy with hypersynchronous onset of seizures, deep electrode recordings from the hippocampus show increase in frequency of interictal spikes with spike-and-wave shape (corresponding to frequency of $3 \mathrm{~Hz}$ ) during the very initial stage of a seizure (Engel, 1989). Thus, enhanced dentate filtering of these frequencies might disrupt seizure propagation. Accordingly, in vivo, we found a delay in kainic acid-induced seizure onset and neuroprotection of the hippocampal neurons. Both effects were abolished after in vivo NPY scavenging within the hilar region.

NPY is stored in dense-core vesicles and may require highfrequency stimulation for its release (Hokfelt, 1991). However, spontaneous or tonic NPY release has been reported in the hippocampus (Tu et al., 2005) and in the hypothalamus (Fu et al., 2004). We found that NPY participates in transmission determined by the paired-pulse paradigm in the $\beta$-estradiol-treated rats, suggesting that spontaneous release of increased NPY may account for the results here.

Our data show that the NPY-mediated enhancement of perforant path-granule cell network inhibition involves activation of NPY $Y_{1}$ receptors. The $Y_{1}$ receptor antagonist PD 160170 completely blocked the $\beta$-estradiol-induced inhibition enhancement at interstimulus intervals of 200-300 ms. Activation of presynaptic $Y_{1}$ receptors in the dentate gyrus has been shown to suppress glutamate release (Silva et al., 2001), which is consistent with an inhibitory effect on neuronal activity. Conversely, blockade of $\mathrm{Y}_{2}$ receptors did not affect the late paired-pulse inhibition using our paired-pulse paradigm by stimulating the mixed perforant path, which suggests that the $\mathrm{Y}_{2}$ receptors may not be involved in regulation of neuronal activity at perforant path-granule cells synapses. This is in accordance with binding studies showing that $\mathrm{Y}_{2}$ receptors are mainly located in the hilar region, whereas the $\mathrm{Y}_{1}$ receptors are within the molecular layer (Gobbi et al., 1998). We also did not find any involvement of the $\mathrm{Y}_{5}$ receptors, which is most likely attributable to the fact that these receptors are expressed in ventral rather than dorsal hippocampus (Dumont et al., 1998).

No effect of $\beta$-estradiol was found on paired-pulse intervals between 10 and $100 \mathrm{~ms}$. These intervals correspond to early inhibition and intermediate facilitation phases of the paired-pulse paradigm, which are sensitive to changes in fast neurotransmission. Thus, these results suggest that fast neurotransmission mediated via ionotropic receptor systems is not affected by the $\beta$-estradiol treatment paradigm. This finding is similar to the findings in the CA1 region reported by others (Smith and McMahon, 2005).

Because the last $\beta$-estradiol injection was $24 \mathrm{~h}$ before testing, the $\beta$-estradiol-induced effects seem to involve genomic action mediated by intracellular estrogen receptors (Gruber et al., 2002). The contribution of acute, membrane effects of $\beta$-estradiol is unlikely because the NPY-dependent increase in the paired-pulse inhibition could not be detected after a single $\beta$-estradiol injection.

The paired-pulse paradigm revealed that $\beta$-estradiol treatment also activated mGluRs. Because activation of groups II and III mGluR increases NPY expression in the hippocampus (Smialowska and Bajkowska, 1997; Schwarzer and Sperk, 1998), this raises a possibility that the $\beta$-estradiol-induced increase in NPY expression may be induced indirectly by activation of the mGluR system. However, a single mGluR-activating stimulus within $24 \mathrm{~h}$ before the NPY assay already effectively increased the NPY expression (Smialowska and Bajkowska, 1997; Schwarzer and Sperk, 1998). Acute application of $\beta$-estradiol on hippocampal cultures has been shown to activate mGluRs (Boulware et al., 2005). This effect seems to involve membrane estrogen receptors, because the mGluR activation occurs very rapidly (Boulware et al., 2005). Thus, one would expect to find the enhanced NPYmediated inhibition already after a single $\beta$-estradiol injection as a result of the acute activation of mGluRs. However, there were no changes in the paired-pulse paradigm at any interstimulus interval after one $\beta$-estradiol injection. Finally, we found that, after blocking mGluRs by bath application of the mGluR antagonist LY 341495, the enhanced response at interstimulus intervals between 200 and $300 \mathrm{~ms}$ sensitive to the anti-NPY antibody is still present. Together, these results suggest that the $\beta$-estradiolinduced effects on the NPY and mGluR system may be independent from each other.

The dentate gyrus plays an important function in cognitive processes (Kirkby and Higgins, 1998; Pastalkova et al., 2006). The $\beta$-estradiol-induced increase in dentate gyrus filtering at selective frequencies may have an important role in these physiological tasks by improving information processing. The decline of hippocampal NPY attributable to the lack of $\beta$-estradiol may be involved in learning and memory disturbances and changes in mood, including increased anxiety states in women after menopause (medical or natural) (Hattiangady et al., 2005; Osterlund et al., 2005). These clinical observations are supported by animal studies, which also show that ovariectomy leads to decline in learning and memory and to increased anxiety in females, all of which can be corrected by $\beta$-estradiol replacement (El-Bakri et al., 2004; Imwalle et al., 2005). Similarly, changes in the NPY system are associated with disturbances in learning and memory as well as anxiety behaviors (Heilig, 2004; Redrobe et al., 2004). These parallel effects of $\beta$-estradiol and NPY may imply a common pathway of action and interactions between both systems. Thus, our data identify a mechanism mediating estrogen-induced regulation of hippocampal physiology. This mechanism may constitute a novel therapeutic target for the design of treatments to preserve or restore impaired hippocampal function. 


\section{References}

Baraban SC, Tallent MK (2004) Interneuron diversity series: interneuronal neuropeptides-endogenous regulators of neuronal excitability. Trends Neurosci 27:135-142.

Behr J, Lyson KJ, Mody I (1998) Enhanced propagation of epileptiform activity through the kindled dentate gyrus. J Neurophysiol 79:1726-1732.

Ben-Ari Y, Tremblay E, Riche D, Ghilini G, Naquet R (1981) Electrographic, clinical and pathological alterations following systemic administration of kainic acid, bicuculline or pentetrazole: metabolic mapping using the deoxyglucose method with special reference to the pathology of epilepsy. Neuroscience 6:1361-1391.

Boulware MI, Weick JP, Becklund BR, Kuo SP, Groth RD, Mermelstein PG (2005) Estradiol activates group I and II metabotropic glutamate receptor signaling, leading to opposing influences on cAMP response elementbinding protein. J Neurosci 25:5066-5078.

Buckmaster PS, Schwartzkroin PA (1995) Interneurons and inhibition in the dentate gyrus of the rat in vivo. J Neurosci 15:774-789.

de Lanerolle NC, Kim JH, Robbins RJ, Spencer DD (1989) Hippocampus interneuron loss and plasticity in human temporal lobe epilepsy. Brain Res 495:387-395.

Derbenev AV, Monroe MJ, Glatzer NR, Smith BN (2006) Vanilloidmediated heterosynaptic facilitation of inhibitory synaptic input to neurons of the rat dorsal motor nucleus of the vagus. J Neurosci 26:9666-9672.

Dube C, Brunson KL, Eghbal-Ahmadi M, Gonzalez-Vega R, Baram TZ (2005) Endogenous neuropeptide Y prevents recurrence of experimental febrile seizures by increasing seizure threshold. J Mol Neurosci 25:275-284.

Dumont Y, Fournier A, Quirion R (1998) Expression and characterization of the neuropeptide $\mathrm{Y} \mathrm{Y}_{5}$ receptor subtype in the rat brain. J Neurosci 18:5565-5574.

El Bahh B, Lurton D, Sundstrom LE, Rougier A (1997) Induction of tolerance and mossy fibre neuropeptide- $Y$ expression in the contralateral hippocampus following a unilateral intrahippocampal kainic acid injection in the rat. Neurosci Lett 227:135-139.

El Bahh B, Auvergne R, Lere C, Brana C, Le Gal La Salle G, Rougier A (2001) Decreased epileptic susceptibility correlates with neuropeptide $\mathrm{Y}$ overexpression in a model of tolerance to excitotoxicity. Brain Res 894:209-217.

El Bahh B, Cao JQ, Beck-Sickinger AG, Colmers WF (2002) Blockade of neuropeptide Y(2) receptors and suppression of NPY's anti-epileptic actions in the rat hippocampal slice by BIIE0246. Br J Pharmacol 136:502-509.

El Bahh B, Balosso S, Hamilton T, Herzog H, Beck-Sickinger AG, Sperk G, Gehlert DR, Vezzani A, Colmers WF (2005) The anti-epileptic actions of neuropeptide $\mathrm{Y}$ in the hippocampus are mediated by $\mathrm{Y} 2$ and not $\mathrm{Y} 5$ receptors. Eur J Neurosci 22:1417-1430.

El-Bakri NK, Islam A, Zhu S, Elhassan A, Mohammed A, Winblad B, Adem A (2004) Effects of estrogen and progesterone treatment on rat hippocampal NMDA receptors: relationship to Morris water maze performance. J Cell Mol Med 8:537-544.

Engel Jr J (1989) Seizures and epilepsy. Philadelphia: Davis.

Engel Jr J, Williamson PD, Wieser H-G (1997) Mesial temporal lobe epilepsy. In: Epilepsy: a comprehensive textbook (Engel Jr J, Pedley TA, eds), pp 2417-2426. Philadelphia: Lippincot-Raven.

Fitzjohn SM, Bortolotto ZA, Palmer MJ, Doherty AJ, Ornstein PL, Schoepp DD, Kingston AE, Lodge D, Collingridge GL (1998) The potent mGlu receptor antagonist LY341495 identifies roles for both cloned and novel mGlu receptors in hippocampal synaptic plasticity. Neuropharmacology 37:1445-1458.

Freund TF, Buzsaki G (1996) Interneurons of the hippocampus. Hippocampus 6:347-470.

Fu LY, Acuna-Goycolea C, van den Pol AN (2004) Neuropeptide Y inhibits hypocretin/orexin neurons by multiple presynaptic and postsynaptic mechanisms: tonic depression of the hypothalamic arousal system. J Neurosci 24:8741-8751.

Gobbi M, Gariboldi M, Piwko C, Hoyer D, Sperk G, Vezzani A (1998) Distinct changes in peptide YY binding to, and mRNA levels of, Y1 and Y2 receptors in the rat hippocampus associated with kindling epileptogenesis. J Neurochem 70:1615-1622.

Gruber CJ, Tschugguel W, Schneeberger C, Hyber JC (2002) Production and actions of estrogens. N Engl J Med 346:340-352.

Haas KZ, Sperber EF, Moshé SL, Stanton PK (1996) Kainic acid-induced seizures enhance dentate gyrus inhibition by downregulation of $\mathrm{GABA}_{\mathrm{B}}$ receptors. J Neurosci 16:4250-4260.

Hattiangady B, Rao MS, Shetty GA, Shetty AK (2005) Brain-derived neurotrophic factor, phosphorylated cyclic AMP response element binding protein and neuropeptide $\mathrm{Y}$ decline as early as middle age in the dentate gyrus and CA1 and CA3 subfields of the hippocampus. Exp Neurol 195:353-371.

Heilig M (2004) The NPY system in stress, anxiety and depression. Neuropeptides 38:213-224.

Heinemann U, Beck H, Dreier JP, Ficker E, Stabel J, Zhang CL (1992) The dentate gyrus as a regulated gate for the propagation of epileptiform activity. Epilepsy Res Suppl 7:273-280.

Hoffman GE, Moore N, Fiskum G, Murphy AZ (2003) Ovarian steroid modulation of seizure severity and hippocampal cell death after kainic acid treatment. Exp Neurol 182:124-134.

Hokfelt T (1991) Neuropeptides in perspective: the last ten years. Neuron 7:867-879.

Imwalle DB, Gustafsson JA, Rissman EF (2005) Lack of functional estrogen receptor beta influences anxiety behavior and serotonin content in female mice. Physiol Behav 84:157-163.

Kalita K, Szymczak S, Kaczmarek L (2005) Non-nuclear estrogen receptor beta and alpha in the hippocampus of male and female rats. Hippocampus 15:404-412.

Kirkby DL, Higgins GA (1998) Characterization of perforant path lesions in rodent models of memory and attention. Eur J Neurosci 10:823-838.

Klapstein GJ, Colmers WF (1997) Neuropeptide Y suppresses epileptiform activity in rat hippocampus in vitro. J Neurophysiol 78:1651-1661.

Lothman EW, Stringer JL, Bertram EH (1992) The dentate gyrus as a control point for seizures in the hippocampus and beyond. Epilepsy Res Suppl 7:301-313.

Martin JL, Sloviter RS (2001) Focal inhibitory interneuron loss and principal cell hyperexcitability in the rat hippocampus after microinjection of a neurotoxic conjugate of saporin and a peptidase-resistant analog of Substance P. J Comp Neurol 436:127-152.

Mathern GW, Babb TL, Armstrong DL (1997) Hippocampal sclerosis. In: Epilepsy: a comprehensive textbook (Engel JJ, Pedley TA, eds), pp 133155. Philadelphia: Lippincott-Raven.

McEwen B (2002) Estrogen actions throughout the brain. Recent Prog Horm Res 57:357-384.

Medvedev A, Mackenzie L, Hiscock JJ, Willoughby JO (2000) Kainic acid induces distinct types of epileptiform discharge with differential involvement of hippocampus and neocortex. Brain Res Bull 52:89-98.

Milner TA, McEwen BS, Hayashi S, Li CJ, Reagan LP, Alves SE (2001) Ultrastructural evidence that hippocampal alpha estrogen receptors are located at extranuclear sites. J Comp Neurol 429:355-371.

Nakamura NH, McEwen BS (2005) Changes in interneuronal phenotypes regulated by estradiol in the adult rat hippocampus: a potential role for neuropeptide Y. Neuroscience 136:357-369.

Neal-Perry GS, Zeevalk GD, Santoro NF, Etgen AM (2005) Attenuation of preoptic area glutamate release correlates with reduced luteinizing hormone secretion in middle-aged female rats. Endocrinology 146:4331-4339.

Osterlund MK, Witt MR, Gustafsson JA (2005) Estrogen action in mood and neurodegenerative disorders: estrogenic compounds with selective properties-the next generation of therapeutics. Endocrine 28:235-242.

Pastalkova E, Serrano P, Pinkhasova D, Wallace E, Fenton AA, Sacktor TC (2006) Storage of spatial information by the maintenance mechanism of LTP. Science 313:1141-1144.

Paxinos G, Watson C (1998) The rat brain in stereotaxic coordinates, Ed 4: Academic.

Pitkanen A, Nissinen J, Nairismagi J, Lukasiuk K, Grohn OH, Miettinen R, Kauppinen R (2002) Progression of neuronal damage after status epilepticus and during spontaneous seizures in a rat model of temporal lobe epilepsy. Prog Brain Res 135:67-83.

Ratzliff AH, Howard AL, Santhakumar V, Osapay I, Soltesz I (2004) Rapid deletion of mossy cells does not result in a hyperexcitable dentate gyrus: implications for epileptogenesis. J Neurosci 24:2259-2269.

Ravizza T, Galanopoulou AS, Velíšková J, Moshé SL (2002) Sex differences in androgen and estrogen receptor expression in rat substantia nigra during development: an immunohistochemical study. Neuroscience 115:685-696.

Redrobe JP, Dumont Y, Herzog H, Quirion R (2004) Characterization of 
neuropeptide $\mathrm{Y}, \mathrm{Y}(2)$ receptor knockout mice in two animal models of learning and memory processing. J Mol Neurosci 22:159-166.

Reibel S, Andre V, Chassagnon S, Andre G, Marescaux C, Nehlig A, Depaulis A (2000) Neuroprotective effects of chronic estradiol benzoate treatment on hippocampal cell loss induced by status epilepticus in the female rat. Neurosci Lett 281:79-82.

Reibel S, Benmaamar R, Le BT, Larmet Y, Kalra SP, Marescaux C, Depaulis A (2003) Neuropeptide Y delays hippocampal kindling in the rat. Hippocampus 13:557-560.

Richichi C, Lin EJ, Stefanin D, Colella D, Ravizza T, Grignaschi G, Veglianese P, Sperk G, During MJ, Vezzani A (2004) Anticonvulsant and antiepileptogenic effects mediated by adeno-associated virus vector neuropeptide Y expression in the rat hippocampus. J Neurosci 24:3051-3059.

Rudick CN, Woolley CS (2001) Estrogen regulates functional inhibition of hippocampal CA1 pyramidal cells in the adult female rat. J Neurosci 21:6532-6543.

Schwarzer C, Sperk G (1998) Glutamate-stimulated neuropeptide Y mRNA expression in the rat dentate gyrus: a prominent role of metabotropic glutamate receptors. Hippocampus 8:274-288.

Silva AP, Carvalho AP, Carvalho CM, Malva JO (2001) Modulation of intracellular calcium changes and glutamate release by neuropeptide $\mathrm{Y} 1$ and Y2 receptors in the rat hippocampus: differential effects in CA1, CA3 and dentate gyrus. J Neurochem 79:286-296.

Silva AP, Xapelli S, Grouzmann E, Cavadas C (2005) The putative neuroprotective role of neuropeptide $\mathrm{Y}$ in the central nervous system. Curr Drug Targets CNS Neurol Disord 4:331-347.

Smialowska M, Bajkowska M (1997) Activation of metabotropic glutamate receptors increases neuropeptide $\mathrm{Y}$ expression in the rat hippocampus. Immunohistochemical studies. Pol J Pharmacol 49:357-362.

Smith CC, McMahon LL (2005) Estrogen-induced increase in the magnitude of long-term potentiation occurs only when the ratio of NMDA transmission to AMPA transmission is increased. J Neurosci 25:7780-7791.

Sperk G, Marksteiner J, Gruber B, Bellmann R, Mahata M, Ortler M (1992) Functional changes in neuropeptide $\mathrm{Y}$ - and somatostatin-containing neurons induced by limbic seizures in the rat. Neuroscience 50:831-846.

Tashiro A, Sandler VM, Toni N, Zhao C, Gage FH (2006) NMDA-receptormediated, cell-specific integration of new neurons in adult dentate gyrus. Nature 442:929-933.

Titolo D, Cai F, Belsham DD (2006) Coordinate regulation of Neuropeptide $\mathrm{Y}$ and Agouti-related peptide gene expression by estrogen depends on the ratio of $\operatorname{ER} \alpha$ to $\operatorname{ER} \beta$ in clonal hypothalamic neurons. Mol Endocrinol 20:2080-2092.

Tu B, Timofeeva O, Jiao Y, Nadler JV (2005) Spontaneous release of neuropeptide $\mathrm{Y}$ tonically inhibits recurrent mossy fiber synaptic transmission in epileptic brain. J Neurosci 25:1718-1729.

Velíšek L, Velišková J (2002) Estrogen treatment protects GABA(B) inhibition in the dentate gyrus of female rats after kainic acid-induced status epilepticus. Epilepsia 43 [Suppl 5]:146-151.

Velíšek L, Velíšková J, Etgen AM, Stanton PK, Moshé SL (1999) Regionspecific modulation of limbic seizure susceptibility by ovarian steroids. Brain Res 842:132-138.

Velíšková J (2003) The role of neuropeptide Y in estrogen-induced neuroprotective effects on status epilepticus-associated hippocampal cell loss. Epilepsia 44 [Suppl 9]:206.

Velíšková J (2006) The role of estrogens in seizures and epilepsy: the bad guys or the good guys? Neuroscience 138:837-844.

Velí̌̌ková J (2007) Estrogens and epilepsy: why are we so excited? Neuroscientist 13:77-88.

Velíšková J, Velíšek L, Galanopoulou AS, Sperber EF (2000) Neuroprotective effects of estrogens on hippocampal cells in adult female rats after status epilepticus. Epilepsia 41:S30-S35.

Vezzani A, Sperk G (2004) Overexpression of NPY and Y2 receptors in epileptic brain tissue: an endogenous neuroprotective mechanism in temporal lobe epilepsy? Neuropeptides 38:245-252.

Vezzani A, Sperk G, Colmers WF (1999) Neuropeptide Y: emerging evidence for a functional role in seizure modulation. Trends Neurosci 22:25-30.

West MJ (2002) Design-based stereological methods for counting neurons. Prog Brain Res 135:43-51.

Wielgosz-Collin G, Duflos M, Pinson P, Le Baut G, Renard P, Bennejean C, Boutin J, Boulanger M (2002) 8-Amino-5-nitro-6-phenoxyquinolines: potential non-peptidic neuropeptide Y receptor ligands. J Enzyme Inhib Med Chem 17:449-453.

Woldbye DP, Nanobashvili A, Sorensen AT, Husum H, Bolwig TG, Sorensen G, Ernfors P, Kokaia M (2005) Differential suppression of seizures via Y2 and Y5 neuropeptide Y receptors. Neurobiol Dis 20:760-772.

Woolley CS, Weiland NG, McEwen BS, Schwartzkroin PA (1997) Estradiol increases the sensitivity of hippocampal CA1 pyramidal cells to NMDA receptor-mediated synaptic input: correlation with dendritic spine density. J Neurosci 17:1848-1859. 